\title{
Article \\ Metabolic Changes in Early-Stage Non-Small Cell Lung Cancer Patients after Surgical Resection
}

\author{
Naseer Ahmed ${ }^{1,2, *}$, Biniam Kidane ${ }^{1,3,4}{ }^{\mathbb{D}}$, Le Wang ${ }^{5,6}$, Zoann Nugent ${ }^{5}$, Nataliya Moldovan ${ }^{2}$, April McElrea ${ }^{6}$, \\ Shiva Shariati-Ievari ${ }^{6}$, Gefei Qing ${ }^{7}$, Lawrence Tan ${ }^{4}$, Gordon Buduhan ${ }^{4}$, Sadeesh K. Srinathan ${ }^{4}$ and \\ Michel Aliani $6,8, *$ (D)
}

1 Research Institute in Oncology and Hematology, CancerCare Manitoba, Winnipeg, MB R3E 0V9, Canada; bkidane@hsc.mb.ca

2 Department of Radiology, Section of Radiation Oncology, Rady Faculty of Health Sciences, University of Manitoba, Winnipeg, MB R3T 2N2, Canada; nmoldovan@cancercare.mb.ca

3 Department of Community Health Sciences, Rady Faculty of Health Sciences, University of Manitoba, Winnipeg, MB R3E 0W3, Canada

4 Department of Surgery, Rady Faculty of Health Sciences, University of Manitoba, Winnipeg, MB R3A 1R9, Canada; LTan@hsc.mb.ca (L.T.); gbuduhan@hsc.mb.ca (G.B.); ssrinathan@hsc.mb.ca (S.K.S.)

5 CancerCare Manitoba, Winnipeg, MB R3E 0V9, Canada; wang1319@myumanitoba.ca (L.W.); znugent@cancercare.mb.ca (Z.N.)

6 St. Boniface Hospital Albrechtsen Research Centre, Winnipeg, MB R2H 2A6, Canada; AMcElrea@sbrc.ca (A.M.); SShariati@sbrc.ca (S.S.-I.)

7 Department of Pathology, Rady Faculty of Health Sciences, University of Manitoba, Winnipeg, MB R3E 3P5, Canada; GQing@sharedhealthmb.ca

check for updates

Citation: Ahmed, N.; Kidane, B.; Wang, L.; Nugent, Z.; Moldovan, N.; McElrea, A.; Shariati-Ievari, S.; Qing, G.; Tan, L.; Buduhan, G.; et al. Metabolic Changes in Early-Stage Non-Small Cell Lung Cancer Patients after Surgical Resection. Cancers 2021, 13, 3012. https://doi.org/10.3390/ cancers 13123012

Academic Editor: Jan Bussink

Received: 4 May 2021

Accepted: 11 June 2021

Published: 16 June 2021

Publisher's Note: MDPI stays neutral with regard to jurisdictional claims in published maps and institutional affiliations.

Copyright: (c) 2021 by the authors. Licensee MDPI, Basel, Switzerland. This article is an open access article distributed under the terms and conditions of the Creative Commons Attribution (CC BY) license (https:// creativecommons.org/licenses/by/ $4.0 /)$.
8 Department of Food and Human Nutritional Sciences, University of Manitoba, Winnipeg, MB R3T 2N2, Canada

* Correspondence: nahmed2@cancercare.mb.ca (N.A.); Michel.Aliani@umanitoba.ca (M.A.)

Simple Summary: Considerable progress in the treatment of non-small cell lung cancer (NSCLC) has been made possible by large-scale technologies that scan the gene expression in tumor cells. While gene expression is informative, it is the changes to cellular metabolism that directly affect the initiation and the progression of the disease. Altered metabolic processes in cancer include how the tumor cells handle fat, proteins, and sugar, produce energy, divide (grow), or migrate. We have used nuclear magnetic resonance and mass spectrometry to survey and document the metabolic changes in blood and urine samples collected from NSCLC patients before and after their lung tumors were surgically removed. We found several molecular compounds that changed in abundance in the blood or urine after surgery, many of which are related to cancer cell metabolism. Further documentation of these changes in large patient populations will lead to non-invasive ways to screen, diagnose, or monitor disease progression in lung cancer patients.

Abstract: Metabolic alterations in malignant cells play a vital role in tumor initiation, proliferation, and metastasis. Biofluids from patients with non-small cell lung cancer (NSCLC) harbor metabolic biomarkers with potential clinical applications. In this study, we assessed the changes in the metabolic profile of patients with early-stage NSCLC using mass spectrometry and nuclear magnetic resonance spectroscopy before and after surgical resection. A single cohort of 35 patients provided a total of 29 and 32 pairs of urine and serum samples, respectively, pre-and post-surgery. We identified a profile of 48 metabolites that were significantly different pre- and post-surgery: 17 in urine and 31 in serum. A higher proportion of metabolites were upregulated than downregulated post-surgery $(p<0.01)$; however, the median fold change (FC) was higher for downregulated than upregulated metabolites $(p<0.05)$. Purines/pyrimidines and proteins had a larger dysregulation than other classes of metabolites ( $p<0.05$ for each class). Several of the dysregulated metabolites have been previously associated with cancer, including leucyl proline, asymmetric dimethylarginine, isopentenyladenine, fumaric acid (all downregulated post-surgery), as well as N6-methyladenosine and several deoxycholic acid moieties, which were upregulated post-surgery. This study establishes metabolomic analysis of biofluids as a path to non-invasive diagnostics, screening, and monitoring in NSCLC. 
Keywords: lung cancer; surgical resection; metabolomics; biofluids

\section{Introduction}

There has been considerable progress in our understanding of lung cancer biology in the last two decades. Checkpoint inhibitors against the programmed death ligand-1 (PD-L1) as a primary treatment or in combination with chemotherapy have changed the landscape of non-small cell lung cancer (NSCLC) with significantly improved outcomes [1]. Several actionable driver mutations, namely epidermal growth factor receptor (EGFR), anaplastic lymphoma kinase (ALK), and c-ros oncogene 1kinase (ROS1), have been identified using next-generation sequencing techniques, resulting in specifically targeted drug therapy and improved outcomes in patients harboring these mutations [2-4]. While it is true that genomics, transcriptomics, and proteomics may predict the biological behavior of malignant cells, it is their metabolic alterations that play a direct and vital role in tumor initiation, proliferation, and metastasis. Some examples of metabolic alterations that are critical to the survival and proliferation of malignant cells include accelerated glycolysis, the formation of lactic acid, changes in the citric acid cycle, amino acid metabolism, and cell membrane synthesis [5-9]. Metabolomics research therefore offers a means to observe the current status of the cellular microenvironment. Recently, there has been movement to develop and incorporate metabolomics in NSCLC research to uncover the biomarkers for applications such as screening, pathogenesis, histopathological classification, and possible therapeutic interventions [8]. Biofluids from NSCLC patients (including serum, urine, exhaled breath condensate, and sputum) have been found to harbor specific metabolic biomarkers with potential applications in clinical practice [10-16].

To date, the clinical application of metabolomics in general is limited due to several factors, including a lack of adequately controlled studies (i.e., incomparable patient populations) and a lack of standardized procedures for metabolite extraction, processing, and analysis [17]. Here, we applied metabolomics to serum and urine samples from a single patient population collected before and after surgical resection. We have applied two complementary and commonly used platforms to identify metabolites of interest: nuclear magnetic resonance (NMR) and liquid chromatography quadrupole time-of-flight mass spectrometry (LC-QTOF-MS). NMR can detect multiple metabolites in a short time with minimal sample preparation; LC-QTOF-MS is much more sensitive than NMR and can detect metabolites of very low concentrations $[18,19]$. We therefore present a prospective observational study in patients with known or suspected early-stage NSCLC and compare their metabolic profiles, screened by these two methods, from serum and urine collected before and after surgery. We hypothesized that the surgical resection of a malignant tumor affects the overall metabolome and causes significant changes in the concentrations of metabolites found in commonly analyzed biofluids. The main objective of this study was therefore to examine the overall metabolomic changes in serum and urine samples collected from patients with early-stage NSCLC before and after the surgical removal of the malignancy. This study opens a path to the development of non-invasive diagnostics, screening, and/or monitoring methods in managing NSCLC.

\section{Materials and Methods}

\subsection{Patient Enrollment and Biofluid Sample Collection}

Protocols were approved by the Research Ethics Board of the University of Manitoba, Canada (H2017:247). Each patient consented to participate in the study prior to accrual. Consecutive patients were screened for eligibility at a thoracic surgery clinic in Winnipeg, Manitoba, Canada. Eligible participants were adult patients ( $>18$ years) with biopsy-proven or suspected stage I or II NSCLC (based on a maximum standardized uptake value on positron emission tomography or an increasing pulmonary tumor size in serial CT chest scans), and medically operable. Imaging data for each eligible patient were reviewed by 
a thoracic surgeon and a radiation oncologist. Clinical, imaging, surgical, and pathology data for enrolled patients were extracted from hospital paper charts and the Varian Medical Oncology application at Cancer Care Manitoba (CCMB) by a designated research assistant and verified by the principal investigator. All pre- and post-surgery samples were collected and prepared by the same research assistant, according to standardized protocols. Serum and midstream urine samples $(8-10 \mathrm{~mL})$ were collected within 4 weeks pre-surgery and within 4 months post-surgery. All samples were immediately stored at $-80{ }^{\circ} \mathrm{C}$ and transferred to the laboratory for batched analysis by NMR and LC-QTOF-MS.

\subsection{Nuclear Magnetic Resonance (NMR) \\ 2.2.1. Sample Preparation for NMR Analysis}

The samples were thawed and prepared with the additives and parameters we have described previously [20]. The serum samples $(300 \mu \mathrm{L})$ were mixed with a phosphate buffer ( $\mathrm{pH}$ 7.4) containing $5 \mu \mathrm{M} \mathrm{NaN}_{3}$ at a ratio of $1: 1(v / v)$, followed by the addition of $20 \mu \mathrm{L}$ of TSP $(0.75 \%)$. The urine samples $(400 \mu \mathrm{L})$ were mixed with $230 \mu \mathrm{L}$ of a $0.2 \mathrm{M}$ phosphate buffer $\left(0.2 \% w / v \mathrm{NaN}_{3}\right)$ and $70 \mu \mathrm{L}$ of Chenomx ISTD (IS-2, $5 \mathrm{mM} \mathrm{DSS}, 0.2 \%$ $w / v \mathrm{NaN}_{3}$ ). The samples were mixed by vortexing and centrifuged at $12,000 \times g$ at $4{ }^{\circ} \mathrm{C}$ for $5 \mathrm{~min}$. A volume of $600 \mu \mathrm{L}$ of each prepared sample was then transferred into a $5 \mathrm{~mm}$ NMR tube for analysis [20].

\subsubsection{NMR Analysis}

The NMR experiments were conducted on a Bruker Ascend 600 Spectrometer operating at $600.27 \mathrm{MHz}$ for proton nuclei and $150.938 \mathrm{MHz}$ for carbon nuclei. Each sample was subject to two separate scans at a probe temperature of $298 \mathrm{~K}$. A few randomly selected samples were run using the heteronuclear single quantum coherence (HSQC) method for additional analysis with a $65.5 \mathrm{k}$ time domain, a $90^{\circ}$ pulse width of $10 \mu \mathrm{s}$, a spectral width of $16 \mathrm{ppm}$, and a relaxation delay of $5 \mathrm{~s}$. A total of 32 scans, with two dummy scans producing an acquisition time of $4.75 \mathrm{~min}$, were acquired. Water was suppressed (at $2819 \mathrm{~Hz}$, time domain $32.7 \mathrm{k}$ ) in all 1D Nuclear Overhauser Effect Spectroscopy (NOESY) runs. A total of 64 scans and 4 dummy scans were generated during the $7 \mathrm{~min} 45 \mathrm{~s}$ acquisition time. The 2D NMR spectra were achieved with a $90^{\circ}$ pulse width of $10 \mu$ s and a relaxation delay of $1.5 \mathrm{~s}$. The time-domain values for 2D NMR spectra were 2048 and 400 for F1 (16 ppm) and F2 (210 ppm), respectively. An acquisition time of approximately $11 \mathrm{~h}$ was needed to obtain 32 scans and 16 dummy scans. All NMR spectra were processed by MestReNova version $12.0 .0-20080$ as previously reported [20].

\subsection{Liquid Chromatography Quadrupole Time-of-Flight Mass Spectrometry (LC-QTOF-MS) 2.3.1. Sample Preparation for LC-QTOF-MS}

The serum samples $(100 \mu \mathrm{L})$ were spiked with $20 \mu \mathrm{L}$ of Norvaline $(0.03 \mathrm{mg} / \mathrm{mL})$ as an internal standard and extracted with $200 \mu \mathrm{L}$ of acetonitrile (ACN,). The urine samples $(250 \mu \mathrm{L})$ were spiked with $10 \mu \mathrm{L}$ of Norvaline $(0.03 \mathrm{mg} / \mathrm{mL})$ and extracted with $500 \mu \mathrm{L}$ of $\mathrm{ACN}$. The samples were then centrifuged at $12,000 \times \mathrm{g}$ at $4{ }^{\circ} \mathrm{C}$ for $20 \mathrm{~min}$. The supernatants of serum and urine were dried under a gentle stream of $\mathrm{N}_{2}$ and stored at $-20^{\circ} \mathrm{C}$. The dried serum and urine samples were reconstituted with $100 \mu \mathrm{L}$ of $\mathrm{ddH}_{2} \mathrm{O}: \mathrm{ACN}(1: 4)$ and $200 \mu \mathrm{L}$ of ddH2O:ACN (4:1), respectively. Each sample was transferred into a glass insert in a gas chromatography (GC) vial for analysis [20].

\subsubsection{LC-QTOF-MS Analysis}

The urinary and serum metabolites were separated using a 1260 Infinity HPLC system and were detected by a 6538 UHD Accurate Q-TOF MS system (Agilent Technologies, Santa Clara, CA, USA). The ionization of the separated metabolites was performed using an electrospray ionization source operating in positive (ESI+) and negative (ESI-) modes. The separation of the urinary metabolites was achieved using a $2.1 \mathrm{~mm} \times 100 \mathrm{~mm}$, $1.8 \mu \mathrm{m}$ Zorbax SB-Aq column (Agilent Technologies) held at $45^{\circ} \mathrm{C}$ and the serum metabo- 
lites were separated using a $2.1 \mathrm{~mm} \times 50 \mathrm{~mm}, 1.8 \mu \mathrm{m}$ Zorbax Extended-C18 column (Agilent Technologies) which was held at $55{ }^{\circ} \mathrm{C}$. Water $\left(\mathrm{ddH}_{2} \mathrm{O}\right)$ and $\mathrm{ACN}$ with $0.1 \%$ formic acid were used as mobile phases using previously reported gradients [20]. The statistical analysis was carried out using Agilent MassHunter Acquisition software (B.07) and Mass Profiler Professional (MPP, 12.6.) as previously reported [20].

\subsection{Statistical Analysis and Metabolite Identification}

The fold change (FC) was calculated for each metabolite identified by dividing the larger of the pre- and post-surgery samples by the smaller value.

For the metabolites identified by NMR, the FCs between the identified classes of metabolites were compared using the Wilcoxon signed rank or the Kruskal-Wallis tests for the comparison of two or more classes, respectively. The chi-square and Fisher exact tests were used to compare the frequencies of regulatory direction. Within individuals, the preand post-surgery levels of metabolites were compared using the Wilcoxon signed rank test.

For LC-QTOF-MS, the MPP software (12.6.1) was used for the FC analysis by paired $t$ tests ( $p<0.05 ; \geq 2$-fold changes) with an asymptotic $p$ value and the Benjamini-Hochberg multiple correction method was used to identify statistically significant metabolites.

The compounds identified through LC-QTOF-MS were further confirmed by mass spectra, retention time, and confidence scores against the Metlin database with $>79,000$ metabolites including 39,000 lipids and 168,000 peptides [20-22]. All the identified metabolites of significance were then re-classified based on the Human Metabolome Data Base (HMDB) [23].

\section{Results}

\subsection{Patient Enrollment, Inclusion, and Exclusion}

Between March 2018 and November 2019, 56 patients were enrolled in the study. Inclusion and exclusion criteria as well as details of the sample collection are presented in Figure 1. In total, 35 patients were eligible for analysis. From these individuals, NMR and QTOF analyses were completed on the urine samples from 29 patients and on the serum samples from 32 patients, collected both pre- and post-surgery. The mean time for serum and urine collection was 5 and 7 days before surgery and 56 and 57 days after surgery, respectively. Post-surgery, all but two patients had their biofluid samples taken before commencing any systemic therapy. A total of $86 \%$ of the patients were smokers or previous smokers. Each patient had a gross surgical resection of the tumor either through lobectomy/pneumonectomy (60\%) or wedge resection/segmentectomy (40\%). All patients had a confirmed pathological diagnosis of NSCLC, $80 \%$ had adenocarcinoma, $88 \%$ had no pathologically involved nodes (N0), and 12\% had incidental intrapulmonary, hilar, or mediastinal (N1-N2) disease. ALK and PDL1 status was available in 66\% of the patients. All patients had ALK negative tumors and a PDL1 tumor proportion score (TPS) of $>50 \%$ was present in $17 \%$ of the tumors. EGFR status was not available. Mean $( \pm S D)$ tumor size from pre-surgical chest CT scans was $2.4 \pm 1.6 \mathrm{~cm}$. Mean $( \pm \mathrm{SD})$ tumor size from surgical pathology was $2.7 \pm 1.9 \mathrm{~cm}$. The mean maximum PET_SUV was $8.2 \pm 6.5$. The data are summarized in Table 1. 


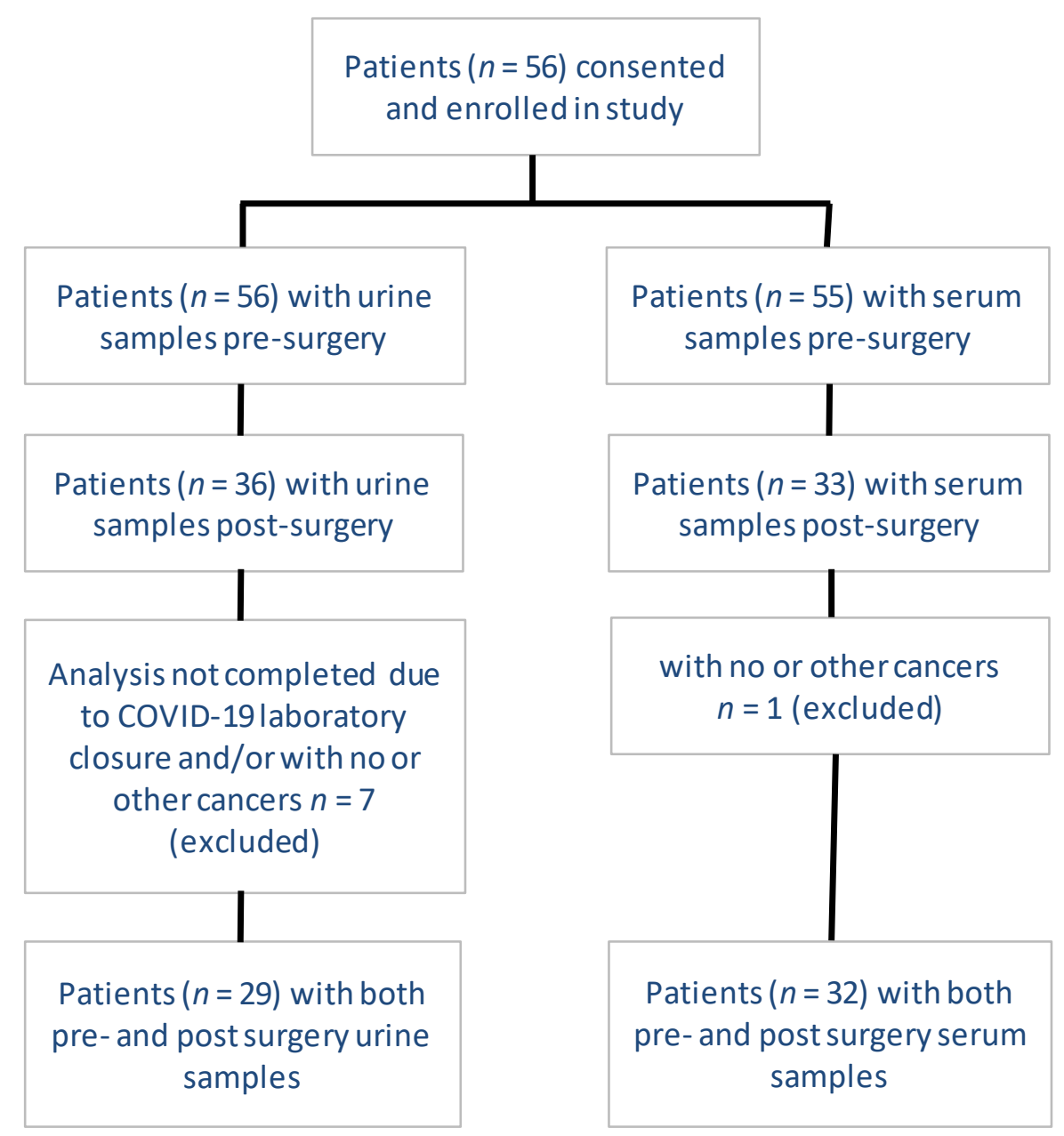

Figure 1. Patient enrollment and biofluid collection.

Table 1. Clinical characteristics of the patient cohort.

\begin{tabular}{cccc}
\hline Characteristics & Total $(\boldsymbol{n}=\mathbf{3 5})$ & Urine $(\boldsymbol{n = 2 9 )}$ & Serum $(\boldsymbol{n}=\mathbf{3 2})$ \\
\hline Age Mean (SD) in years & $64.7(7.4)(n=34)$ & $63.8(7.0)(n=28)$ & $64.6(7.5)(n=31)$ \\
Females & $63 \%(22)$ & $62 \%(18)$ & $62 \%(20)$ \\
Males & $37 \%(13)$ & $38 \%(11)$ & $38 \%(12)$ \\
Smoker & $34 \%(10)$ & $36 \%(10)$ & $35 \%(9)$ \\
Ex-Smoker & $52 \%(15)$ & $50 \%(14)$ & $50 \%(13)$ \\
Never Smoked & $14 \%(4)$ & $14 \%(4)$ & $15 \%(4)$ \\
Diabetes & $17 \%(6)$ & $10 \%(3)$ & $19 \%(6)$ \\
COPD & $49 \%(17)$ & $48 \%(14)$ & $50 \%(16)$ \\
Previous cancers & $29 \%(10)$ & $31 \%(9)$ & $28 \%(9)$ \\
On steroids oral/inhalers & $0 \%$ & $0 \%$ & $0 \%$ \\
Squamous cell carcinoma & $14 \%(5)$ & $14 \%(4)$ & $16 \%(5)$ \\
Adenocarcinoma & $80 \%(28)$ & $79 \%(23)$ & $81 \%(26)$ \\
Other & $6 \%(2)$ & $7 \%(2)$ & $3 \%(1)$ \\
Right Upper Lobe & $29 \%(10)$ & $31 \%(9)$ & $25 \%(8)$ \\
Right Lower Lobe & $20 \%(7)$ & $17 \%(5)$ & $22 \%(7)$ \\
Left Upper Lobe & $31 \%(11)$ & $34 \%(10)$ & $31 \%(10)$ \\
Left Lower Lobe & $19 \%(7)$ & $17 \%(5)$ & $22 \%(7)$ \\
PET before surgery & $86 \%(30)$ & $86 \%(25)$ & $84 \%(27)$ \\
\hline
\end{tabular}


Table 1. Cont.

\begin{tabular}{|c|c|c|c|}
\hline Characteristics & Total $(n=35)$ & Urine $(n=29)$ & Serum $(n=32)$ \\
\hline \multicolumn{4}{|l|}{ Type of surgery: } \\
\hline Wedge Resection/Segmentectomy & $40 \%(14)$ & $38 \%(11)$ & $41 \%(13)$ \\
\hline Lobectomy & $51 \%(18)$ & $55 \%(16)$ & $50 \%(16)$ \\
\hline Pneumonectomy & $3 \%(1)$ & $3 \%(1)$ & $3 \%(1)$ \\
\hline Wedge and Lobectomy & $6 \%(2)$ & $3 \%(1)$ & $6 \%(2)$ \\
\hline Pathological Stage $(n=34)$ & & $n=28$ & $n=31$ \\
\hline T1-T2, N0 M0 & $79 \%(27)$ & $75 \%(21)$ & $77 \%(24)$ \\
\hline T3-T4, N0 M0 & $9 \%(3)$ & $11 \%(3)$ & $10 \%(3)$ \\
\hline T1-T4, N1-2 M0 & $12 \%(4)$ & $14 \%(4)$ & $13 \%(4)$ \\
\hline $\begin{array}{l}\text { Mean Tumor size based on CT scan } \\
\text { before surgical resection Mean (SD) in } \mathrm{cm}\end{array}$ & $2.4(1.6)(n=35)$ & $2.5(1.7)(n=29)$ & $2.5(1.7)(n=32)$ \\
\hline $\begin{array}{l}\text { Mean Tumor size base on surgical } \\
\text { pathology Mean (SD) in cm }\end{array}$ & $2.7(1.9)(n=34)$ & $2.8(2.0)(n=28)$ & $2.8(1.9)(n=31)$ \\
\hline Mean Maximum PET_SUV Mean (SD) & $8.2(6.5)(n=30)$ & $8.2(6.9)(n=25)$ & $8.1(6.7)(n=27)$ \\
\hline PDL1: <1\% $(10 / 23)$ & $43 \%$ & $47 \%(9 / 19)$ & $45 \%(10 / 22)$ \\
\hline PDL1: $1-49 \%(9 / 23)$ & $39 \%$ & $42 \%(8 / 19)$ & $41 \%(9 / 22)$ \\
\hline PDL1: $>50 \%(4 / 23)$ & $17 \%$ & $11 \%(2 / 19)$ & $14 \%(3 / 22)$ \\
\hline ALK: Negative $(n=23)$ & $100 \%$ & $100 \%(n=20)$ & $100 \%(n=22)$ \\
\hline
\end{tabular}

Notes: TNM Staging per AJCC, TNM 6th edition. COPD, chronic obstructive airway disease; SD, standard deviation.

\subsection{Inclusion, Exclusion, and Classification of Identified Metabolites}

A total of 105 metabolites registering statistically significant differences pre- vs. postsurgery were identified by either LC-QTOF or NMR: LC-QTOF registered 71 metabolites of significance in the serum samples and 28 in the urine samples, and NMR registered 12 metabolites of significance in the serum samples and 37 in the urine samples. Of the metabolites identified by NMR, only one in the serum samples and five in the urine samples were included for analysis as those were statistically significant $(p<0.05)$. Each metabolite was reviewed based on the chemical formula, mass and atomic number, presence/absence, and the description of the compound in both HMDB [23] and the National Center for Biotechnology Information (NCBI) database [24]. From this analysis, 57 metabolites identified by LC-QTOF were judged to be either of exogenous origin or related to external substances (prescription drugs, food, or food additives) and were excluded from the analysis.

We therefore identified 48 metabolites of significance in the serum and urine samples and classified these based on their chemical composition and/or metabolic pathway per HMDB. Five classes of metabolites were identified: lipids and derivatives, proteins and derivatives, carboxylic acid and derivatives, carbohydrates, and purines/pyrimidines. The metabolites that did not fit into one of these classes were grouped as unclassified. A metabolite was labeled upregulated or downregulated if the levels increased or decreased after surgery, respectively, expressed as an absolute FC. Metabolites in each class with their respective atomic number/mass, polarity, FC, source biofluid (serum or urine) and the identifying platform (NMR/LC-QTOF) are presented in Table 2. 
Table 2. Classification of altered metabolites of significance.

\begin{tabular}{|c|c|c|c|c|c|c|c|c|c|}
\hline Compound & Formula & $\mathrm{m} / \mathrm{z}$ & Polarity & FC & $p$ Value & Reg & Class & Biofluid & Platform \\
\hline \multicolumn{10}{|c|}{ Lipids and Derivatives } \\
\hline 2-Propylpent-3-enoic acid & $\mathrm{C}_{8} \mathrm{H}_{14} \mathrm{O}_{2}$ & 160.1328 & + & 50 & $<0.0001$ & up & Fatty Acid & Serum & QTOF \\
\hline $\begin{array}{c}\text { 13,14-Dihydro } \\
\text { PGE1/Prostaglandin F1a }\end{array}$ & $\mathrm{C}_{20} \mathrm{H}_{36} \mathrm{O}_{5}$ & 713.493 & + & 5 & 0.047 & up & Prostaglandins & Serum & QTOF \\
\hline 2-Hexenoylcarnitine & $\mathrm{C}_{13} \mathrm{H}_{23} \mathrm{NO}_{4}$ & 258.1654 & + & 16 & 0.013 & up & Acyl Carnitines & Serum & QTOF \\
\hline $\begin{array}{l}\text { 2-Octenoylcarnitine } \\
\text { Chenodeoxycholic/ }\end{array}$ & $\mathrm{C}_{15} \mathrm{H}_{27} \mathrm{NO}_{4}$ & 286.2013 & + & 3 & 0.026 & up & Acyl Carnitines & Serum & QTOF \\
\hline $\begin{array}{c}\text { Deoxycholic acid glycine } \\
\text { conjugate/ }\end{array}$ & $\mathrm{C}_{26} \mathrm{H}_{43} \mathrm{NO}_{5}$ & 450.3208 & + & 28 & 0.0005 & up & Bile Acid & Serum & QTOF \\
\hline \multicolumn{10}{|l|}{ Glycoursodeoxycholic acid } \\
\hline cis-5-Tetradecenoylcarnitine & $\begin{array}{l}\mathrm{C}_{24} \mathrm{H}_{40} \mathrm{O}_{5} \\
\mathrm{C}_{21} \mathrm{H}_{39} \mathrm{NO}_{4}\end{array}$ & $\begin{array}{c}426.3246 \\
370.2948\end{array}$ & $\begin{array}{l}+ \\
+\end{array}$ & $\begin{array}{l}4 \\
4\end{array}$ & $\begin{array}{l}0.026 \\
0.033\end{array}$ & $\begin{array}{l}\text { down } \\
\text { up }\end{array}$ & $\begin{array}{l}\text { Bile Acld } \\
\text { Acyl Carnitines }\end{array}$ & $\begin{array}{l}\text { Serum } \\
\text { Serum }\end{array}$ & QTOF \\
\hline Decanoylcarnitine & $\mathrm{C}_{17} \mathrm{H}_{33} \mathrm{NO}_{4}$ & $3,162,481$ & + & 2 & 0.0001 & up & Acyl Carnitines & Serum & QTOF \\
\hline Dodecanoylcarnitine & $\mathrm{C}_{19} \mathrm{H}_{38} \mathrm{NO}_{4}$ & 344.2792 & + & 6 & 0.0009 & up & Acyl Carnitines & Serum & QTOF \\
\hline Isopentenyladenine & $\mathrm{C}_{16} \mathrm{H}_{23} \mathrm{~N}_{5} \mathrm{O}_{5}$ & 204.1242 & + & 31 & 0.0001 & down & $\begin{array}{l}\text { Mevalonate } \\
\text { Pathway }\end{array}$ & Urine & QTOF \\
\hline L-Carnitine & $\mathrm{C}_{7} \mathrm{H}_{15} \mathrm{NO}_{3}$ & 162.1124 & + & 3 & $<0.0001$ & up & $\begin{array}{l}\text { Carnitines (Lipid } \\
\text { Metabolism) }\end{array}$ & Serum & QTOF \\
\hline L-Octanoylcarnitine & $\mathrm{C}_{15} \mathrm{H}_{29} \mathrm{NO}_{4}$ & 288.2166 & + & 2 & 0.0008 & up & acyl carnitines & Serum & QTOF \\
\hline LysoPC(P-18:1) & $\mathrm{C}_{26} \mathrm{H}_{52} \mathrm{NO}_{7} \mathrm{P}$ & 522.3552 & + & 3 & 0.026 & up & Fatty Acid & Serum & QTOF \\
\hline PG(18:1/18:2) & $\mathrm{C}_{42} \mathrm{H}_{77} \mathrm{O}_{10} \mathrm{P}$ & 773.536 & + & 6 & 0.0087 & up & $\begin{array}{l}\text { phosphatidyl } \\
\text { glycerols }\end{array}$ & Serum & QTOF \\
\hline PI(16:0/18:1) & $\mathrm{C}_{43} \mathrm{H}_{81} \mathrm{O}_{13} \mathrm{P}$ & $854.5691 \wedge$ & + & 7 & 0.0002 & down & $\begin{array}{l}\text { phosphatidy } \\
\text { linositols }\end{array}$ & Serum & QTOF \\
\hline \multicolumn{10}{|c|}{ Proteins and Derivatives } \\
\hline 4-Guanidinobutanoic acid & $\mathrm{C}_{5} \mathrm{H}_{11} \mathrm{~N}_{3} \mathrm{O}_{2}$ & $163.1156^{\wedge}$ & + & 4 & 0.029 & up & $\begin{array}{c}\text { amino acid } \\
\text { (Gamma) }\end{array}$ & Serum & QTOF \\
\hline Aspartyl glycine & $\mathrm{C}_{8} \mathrm{H}_{13} \mathrm{~N}_{3} \mathrm{O}_{6}$ & 248.0938 & + & 50 & 0.0006 & down & dipeptide & Urine & QTOF \\
\hline $\begin{array}{l}\text { Asymmetric dimethylarginine } \\
\text { (ADMA) }\end{array}$ & $\mathrm{C}_{8} \mathrm{H}_{18} \mathrm{~N}_{4} \mathrm{O}_{2}$ & 203.1505 & + & 16 & 0.044 & down & amino acid & Urine & QTOF \\
\hline Hypoglycin & $\mathrm{C}_{7} \mathrm{H}_{11} \mathrm{NO}_{2}$ & 142.0875 & + & 442 & $<0.0001$ & up & amino acid & Urine & QTOF \\
\hline Isodesmosine & $\mathrm{C}_{24} \mathrm{H}_{40} \mathrm{~N}_{5} \mathrm{O}_{8}$ & 527.296 & + & 19 & 0.043 & up & amino acid & Serum & QTOF \\
\hline $\begin{array}{l}\text { L-Glutamic acid n-butyl } \\
\text { ester }\end{array}$ & $\mathrm{C}_{9} \mathrm{H}_{17} \mathrm{NO}_{4}$ & 204.1233 & + & 65 & 0.0009 & up & amino acid & Urine & QTOF \\
\hline L-Isoleucyl-L-proline & $\mathrm{C}_{11} \mathrm{H}_{20} \mathrm{~N}_{2} \mathrm{O}_{3}$ & 229.152 & + & 2 & 0.0005 & up & dipeptide & Serum & QTOF \\
\hline $\begin{array}{l}\text { N(alpha)-t-Butoxycarbonyl-L- } \\
\text { leucine }\end{array}$ & $\mathrm{C}_{11} \mathrm{H}_{21} \mathrm{NO}_{4}$ & 232.1547 & + & 161 & $<0.0001$ & down & amino acid & Urine & QTOF \\
\hline Pro Leu & $\mathrm{C}_{11} \mathrm{H}_{20} \mathrm{~N}_{2} \mathrm{O}_{3}$ & 229.1548 & + & 625 & $<0.0001$ & down & dipeptide & Urine & QTOF \\
\hline \multirow{2}{*}{\multicolumn{10}{|c|}{ Carbohydrates }} \\
\hline & & & & & & & & & \\
\hline Myoinositol & $\mathrm{C}_{6} \mathrm{H}_{12} \mathrm{O}_{6}$ & 203.0524 * & - & 2 & 0.0002 & up & Carbohydrate & Serum & QTOF \\
\hline Glyceraldehyde & $\mathrm{C}_{3} \mathrm{H}_{6} \mathrm{O}_{3}$ & $203.0524 *$ & - & 2 & 0.0001 & up & Carbohydrate & Serum & QTOF \\
\hline Glucose & $\mathrm{C}_{6} \mathrm{H}_{12} \mathrm{O}_{6}$ & & & 2 & 0.0499 & up & Carbohydrate & Urine & NMR \\
\hline Lactate & $\mathrm{C}_{3} \mathrm{H}_{5} \mathrm{O}_{3}$ & 203.0524 * & - & 2 & 0.013 & up & $\begin{array}{l}\text { Glycolysis } \\
\text { Product }\end{array}$ & Urine & NMR \\
\hline Beta-Cortol & & & & 8 & 0.013 & down & Carbohydrate & Serum & QTOF \\
\hline \multicolumn{10}{|c|}{ Purine/Pyrimidines } \\
\hline 1-Methyladenine & $\mathrm{C}_{6} \mathrm{H}_{7} \mathrm{~N}_{5}$ & 321.1307 * & + & 59 & $<0.0001$ & up & Purine & Urine & QTOF \\
\hline 3-Methyluric acid & $\mathrm{C}_{6} \mathrm{H}_{6} \mathrm{~N}_{4} \mathrm{O}_{3}$ & 183.0515 & + & 198 & $<0.0001$ & down & Purine & Urine & QTOF \\
\hline $\begin{array}{l}\text { 5-Acetylamino-6-formylamino-3- } \\
\text { methyluracil }\end{array}$ & $\mathrm{C}_{8} \mathrm{H}_{10} \mathrm{~N}_{4} \mathrm{O}_{4}$ & $249.0608 *$ & + & 3 & 0.029 & up & Hydroxypyrimidine & Serum & QTOF \\
\hline N6-Methyladenosine & $\mathrm{C}_{11} \mathrm{H}_{15} \mathrm{~N}_{5} \mathrm{O}_{4}$ & 282.1199 & + & 27 & 0.0085 & up & $\begin{array}{c}\text { purine } \\
\text { nucleoside }\end{array}$ & Urine & QTOF \\
\hline \multicolumn{10}{|c|}{ Carboxylic acid and Derivatives } \\
\hline cis-Aconitate & $\mathrm{C}_{6} \mathrm{H}_{6} \mathrm{O}_{6}$ & & & 1 & 0.035 & up & carboxylic acid & Urine & NMR \\
\hline Malonate & $\mathrm{C}_{3} \mathrm{H}_{3} \mathrm{O}_{4}$ & & & 2 & 0.014 & up & carboxylic acid & Urine & NMR \\
\hline $\begin{array}{l}\text { 4-Hydroxycyclohexylcarboxylic } \\
\text { acid }\end{array}$ & $\mathrm{C}_{7} \mathrm{H}_{12} \mathrm{O}_{3}$ & $162.1126^{\wedge}$ & + & 3 & $<0.0001$ & up & carboxylic acid & Serum & QTOF \\
\hline Fumaric acid & $\mathrm{C}_{4} \mathrm{H}_{4} \mathrm{O}_{4}$ & 139.0026 & + & 17 & 0.011 & down & carboxylic acid & Urine & QTOF \\
\hline Guanidinosuccinic acid & $\mathrm{C}_{5} \mathrm{H}_{9} \mathrm{~N}_{3} \mathrm{O}_{4}$ & 176.0654 & + & 3 & 0.023 & up & $\begin{array}{l}\text { carboxylic acid } \\
\text { (aspartic acid) }\end{array}$ & Serum & QTOF \\
\hline Proline betaine & $\mathrm{C}_{7} \mathrm{H}_{14} \mathrm{NO}_{2}$ & 144.1014 & + & 2 & 0.024 & up & $\begin{array}{c}\text { carboxylic acid } \\
\text { (proline } \\
\text { derivative) }\end{array}$ & Serum & QTOF \\
\hline \multirow{2}{*}{\multicolumn{10}{|c|}{ Unclassified $^{2}$}} \\
\hline & & & & & & & & & \\
\hline Androstanediol & $\mathrm{C}_{19} \mathrm{H}_{32} \mathrm{O}_{2}$ & $623.4382^{\$}$ & + & 54 & $<0.0001$ & down & Androgens & Serum & QTOF \\
\hline Dopamine & $\mathrm{C}_{8} \mathrm{H}_{11} \mathrm{NO}_{2}$ & 154.0823 & + & 5 & $<0.0001$ & up & catecholamine & Serum & QTOF \\
\hline Epinephrine & $\mathrm{C}_{9} \mathrm{H}_{13} \mathrm{NO}_{3}$ & 184.0944 & + & 134 & $<0.0001$ & up & catecholamine & Serum & QTOF \\
\hline Androstenedione & $\mathrm{C}_{19} \mathrm{H}_{26} \mathrm{O}_{2}$ & 287.2041 & + & 8 & 0.023 & up & Androgens & Serum & QTOF \\
\hline $\begin{array}{l}\text { Tetrahydrobiopterin/Sapropterin } \\
\text { (BH4, THB) }\end{array}$ & $\mathrm{C}_{9} \mathrm{H}_{15} \mathrm{~N}_{5} \mathrm{O}_{3}$ & $500.2767 \neq$ & + & 8 & 0.0031 & up & Biopterin & Serum & QTOF \\
\hline N-Desmethylaminopyrine & $\mathrm{C}_{12} \mathrm{H}_{15} \mathrm{~N}_{3} \mathrm{O}$ & 218.1378 & + & 10 & 0.0003 & up & phenylpyrazoles & Serum & QTOF \\
\hline
\end{tabular}




\subsection{Pattern of Frequency and Distribution of the Identified Metabolites}

The distribution and the frequency of the metabolites based on the biofluid, and class are presented in Table 3. There were 31 metabolites of significance in the serum samples and 17 in the urine samples that were not significantly different $(p=0.060)$. Lipids and their derivatives were the most frequently identified, followed by (in decreasing order of frequency) proteins and derivatives, carboxylic acid and derivatives, unclassified carbohydrates, and purines/pyrimidines.

Table 3. Categorization of the metabolites based on biofluid and their chemical class.

\begin{tabular}{cc}
\hline Source or Class of Metabolites & Frequency $\boldsymbol{n} \mathbf{( \% )}$ \\
\hline All & $48(100)$ \\
Serum & $31(65)$ \\
Urine & $17(35)$ \\
Lipids and Derivatives & $15(31)$ \\
Protein and Derivatives & $11(23)$ \\
Carboxylic Acid and Derivatives & $7(15)$ \\
Unclassified & $6(13)$ \\
Carbohydrates & $5(10)$ \\
Purine/Pyrimidines & $4(8)$ \\
\hline
\end{tabular}

\subsection{Pattern of Dysregulation of the Identified Metabolites Post-Surgery}

A higher proportion of metabolites were upregulated $(n=34)$ than were downregulated $(n=14)$ post-surgery $(p=0.0055)$. This ratio varied by biofluid: in serum, these proportions were $84 \%(26 / 31)$ upregulated and $16 \%(5 / 31)$ downregulated $(p=0.0002)$, and in urine, the proportions were similar at $46 \%(8 / 17)$ and 53\% (9/17) up- and downregulated, respectively $(p=1)$. We found no significant differences in the proportion of the upor downregulated metabolites based on chemical class ( $p=0.48$; see Figure 2$)$.

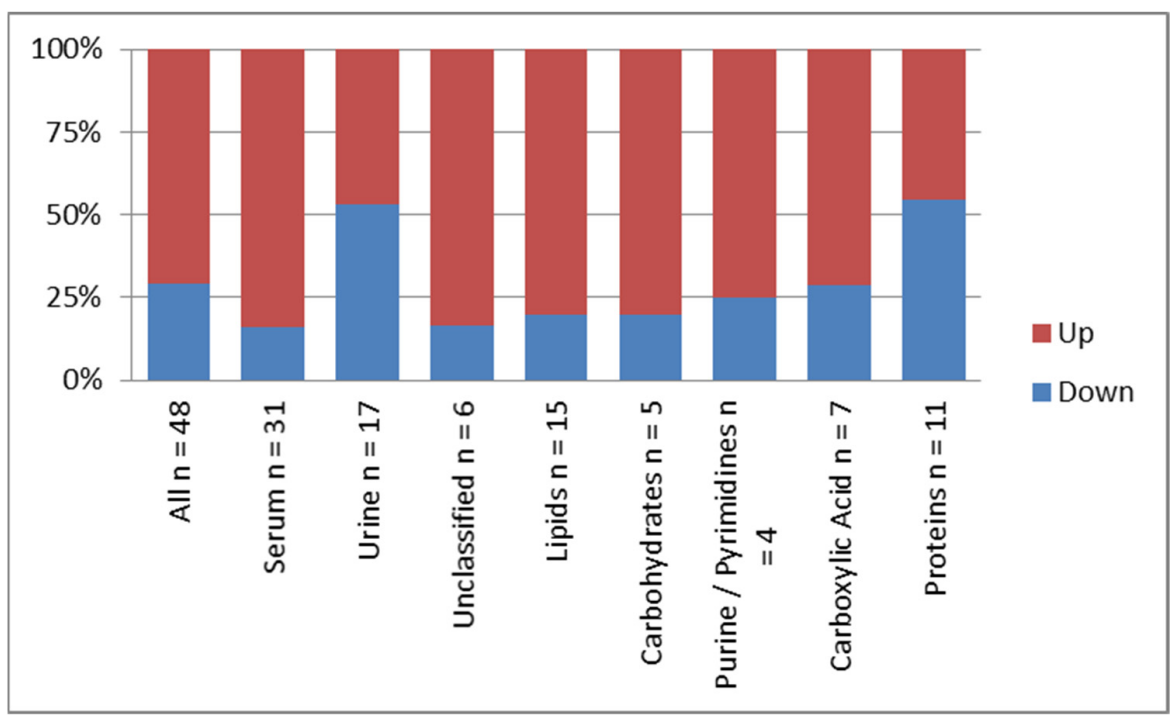

Figure 2. Pattern of regulation of identified metabolites based on biofluid and class of metabolites.

\subsection{Magnitude of Dysregulation of the Identified Metabolites Post-Surgery}

Median, minimum, and maximum changes in the levels of metabolites expressed as an absolute FC after surgery are presented in Table 4 . The median FC was 4 and 16 for all up- and downregulated metabolites, respectively $(p=0.043)$. A similar pattern of dysregulation was observed when the data were grouped by biofluid but this was not significant: for the metabolites identified in the serum samples, the median FC (upand downregulated) was 4 and 7 , respectively ( $p=0.69$ ); for the metabolites identified 
in the urine samples, the median FC change was 14 and 31 , respectively $(p=0.28)$. The maximum FC for upregulated metabolites in the serum and urine samples was 134 and 442 , respectively. The maximum FC for downregulated metabolites in the serum and urine samples was 54 and 625, respectively. Purines/pyrimidines and proteins and derivatives had a larger dysregulation than those in the other classes of metabolites ( $p=0.045$ and $p=0.027$, respectively). Purines/pyrimidines had the highest median FCs of 27 and 198, respectively, for up- and downregulated metabolites, followed by proteins and derivatives with median FCs of 19 and 33, respectively. The median FCs for lipids were 4 and 7 for up- and downregulated metabolites, respectively. Both carbohydrates and carboxylic acid and derivatives had a median FC of 2 for upregulated metabolites; for downregulated metabolites in these categories, the median FC was 8 for carbohydrates and 9 for carboxylic acid and derivatives. For the unclassified metabolites, the median FC was 8 and 54 for the upregulated and downregulated metabolites, respectively. These results are summarized in Figure 3.

Table 4. Fold change (FC) in metabolites post-surgery based on biofluid and chemical class.

\begin{tabular}{|c|c|c|c|c|c|c|c|c|c|}
\hline \multirow[t]{2}{*}{ Class of Metabolites } & \multicolumn{4}{|c|}{ Upregulated } & \multicolumn{4}{|c|}{ Downregulated } & \multirow[t]{2}{*}{$p$ Value } \\
\hline & $\mathbf{N}$ & $\begin{array}{l}\text { Med } \\
\text { FC }\end{array}$ & $\begin{array}{c}\text { Min } \\
\text { FC }\end{array}$ & $\begin{array}{c}\text { Max } \\
\text { FC }\end{array}$ & $n$ & $\begin{array}{l}\text { Med } \\
\text { FC }\end{array}$ & $\begin{array}{l}\text { Min } \\
\text { FC }\end{array}$ & $\begin{array}{c}\text { Max } \\
\text { FC }\end{array}$ & \\
\hline All & 34 & 4 & 1 & $\begin{array}{c}442 \\
\text { Biofluid }\end{array}$ & 14 & 16 & 1 & 625 & 0.043 \\
\hline Serum & 26 & 4 & 2 & 134 & 5 & 7 & 1 & 54 & 0.69 \\
\hline Urine & 8 & 14 & 1 & $\begin{array}{c}442 \\
\text { Class }\end{array}$ & 9 & 31 & 2 & 625 & 0.28 \\
\hline Lipids and derivatives & 12 & 4 & 2 & 50 & 3 & 7 & 4 & 31 & \\
\hline $\begin{array}{l}\text { Proteins and } \\
\text { derivatives }\end{array}$ & 5 & 19 & 2 & 442 & 6 & 33 & 1 & 625 & \\
\hline Carbohydrates & 4 & 2 & 2 & 2 & 1 & 8 & & & \\
\hline Purine/Pyrimidines & 3 & 27 & 3 & 59 & 1 & 198 & & & \\
\hline $\begin{array}{c}\text { Carboxylic acid and } \\
\text { derivatives }\end{array}$ & 5 & 2 & 1 & 3 & 2 & 9 & 2 & 17 & \\
\hline Unclassified & 5 & 8 & 5 & 134 & 1 & 54 & & & \\
\hline
\end{tabular}

Notes: Upregulated indicates that the metabolite level increased post-surgery. Downregulated indicates that the metabolite level decreased post-surgery. $n$, number of metabolites; Max, maximum; Med, median; Min, minimum.

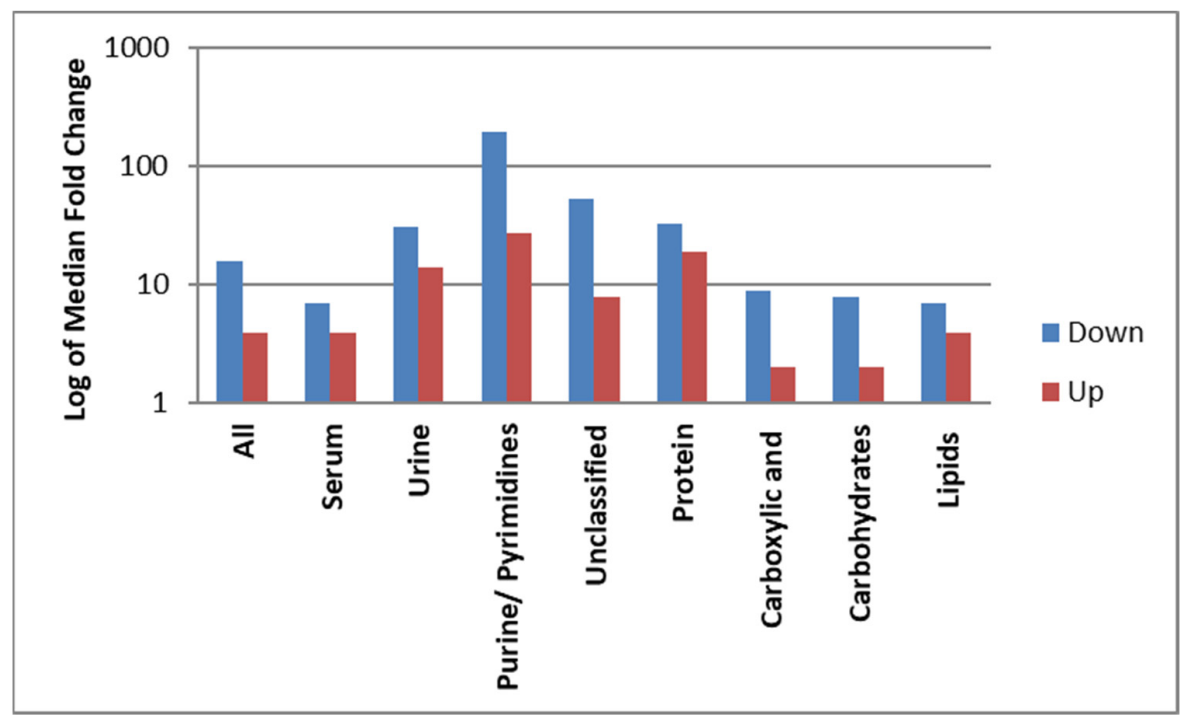

Figure 3. Magnitude of dysregulation. The magnitude of the downregulation of the metabolites after surgery was higher in both the serum and urine samples $(p=0.043)$; although this was not statistically significant, the difference was larger in the urine samples $(p=0.28)$ than the serum samples only $(p=0.69)$. The alteration in purines/pyrimidines $(p=0.045)$ and protein and derivatives $(p=0.027)$ was larger than those in the other classes of metabolites. 


\subsection{Metabolites of Significance with $>10$ FC Dysregulation and Their Association with Pathogenesis of Cancer}

There were 18 metabolites of significance dysregulated by $>10$-fold after surgery. Of these, seven were proteins and derivatives, three were purines, four were lipids, one was a carboxylic acid, one was an androgen, and two were unclassified (see Table 5). Six of these metabolites were directly associated with cancer pathogenesis based on the literature review. Leucyl proline, isopentenyladenine, fumaric acid, and asymmetric dimethylarginine (ADMA) were identified in the urine samples and were downregulated by 625 , 31, 17 and 16-fold, respectively, after surgery. N6-methyladenosine identified in the urine samples, and chenodeoxycholic/deoxycholic/glycoursodeoxycholic acid identified in the serum samples were upregulated with FCs of 27 and 28, respectively. Other metabolites of significance with FC > 100 included 3-methyl uric acid, N(alpha)-t-butoxycarbonyl-Lleucine, hypoglycin, and epinephrine without any previously direct association to cancer pathogenesis.

Table 5. Metabolites of significance (FC > 10).

\begin{tabular}{|c|c|c|c|c|c|}
\hline Class & Biofluid & Metabolite & Regulation & Fold Change & $\begin{array}{l}\text { Previously Known } \\
\text { Association to } \\
\text { Cancer Pathogenesis }\end{array}$ \\
\hline Protein and Derivatives & Urine & Pro Leu & down & 625 & Yes \\
\hline Purine/Pyrimidines & Urine & 3-Methyluric acid & down & 198 & Yes \\
\hline Protein and Derivatives & Urine & $\begin{array}{l}\text { N(alpha)-t-Butoxycarbonyl- } \\
\text { L-leucine }\end{array}$ & down & 161 & No \\
\hline Androgens & Serum & Androstanediol & down & 54 & Yes \\
\hline Protein and Derivatives & Urine & Aspartyl glycine & down & 50 & Yes \\
\hline Lipid and Derivatives & Urine & Isopentenyladenine & down & 31 & Yes \\
\hline $\begin{array}{l}\text { Carboxylic Acid and } \\
\text { Derivatives }\end{array}$ & Urine & Fumaric acid & down & 17 & Yes \\
\hline Protein and Derivatives & Urine & $\begin{array}{c}\text { Asymmetric } \\
\text { dimethylarginine (ADMA) }\end{array}$ & down & 16 & Yes \\
\hline Protein and Derivatives & Urine & Hypoglycin & up & 442 & No \\
\hline Unclassified & Serum & Epinephrine & up & 134 & Yes \\
\hline Protein and Derivatives & Urine & L-Glutamic acid n-butyl ester & up & 65 & Yes \\
\hline Purine/Pyrimidines & Urine & 1-Methyladenine & up & 59 & No \\
\hline Lipid and Derivatives & Serum & 2-Propylpent-3-enoic acid & up & 50 & No \\
\hline Lipid and Derivative & Serum & $\begin{array}{l}\text { Chenodeoxycholic/Deoxycholic/ } \\
\text { Glycoursodeoxycholic acid }\end{array}$ & up & 28 & Yes \\
\hline Purine/Pyrimidines & Urine & N6-Methyladenosine & up & 27 & Yes \\
\hline Protein and Derivative & Serum & Isodesmosine & up & 19 & No \\
\hline Lipid and Derivative & Serum & 2-Hexenoylcarnitine & up & 16 & Possible \\
\hline Unclassified & Serum & N-Desmethylaminopyrine & up & 10.3 & No \\
\hline
\end{tabular}

Notes: Based on the magnitude of alteration of the metabolites ( $>10$ fold) after surgery and previously known association to NSCLC and or any other cancer, six metabolites of significance have been identified marked in bold.

\section{Discussion}

\subsection{Study Desgin and Metobolic Profile}

We conducted an exploratory nontargeted metabolomics study for early-stage NSCLC patients eligible for a curative surgical resection. Two distinct aspects of our study design are (i) the patient population and (ii) the use of a radical treatment intervention to compare the metabolic profile of the same patient population, i.e., before and after the complete removal of a pulmonary cancerous lesion.

The metabolic profile obtained in this study represents a single patient population with small and localized tumors with no or minimum microscopic regional and no systemic metastasis. Surgical removal of the tumors provides a binary metabolic state in the same patient population, i.e., with and without a malignant tumor. Dysregulation of the metabolic profile was observed in the biofluids of these patients with intact pulmonary tumors, followed by a significant change in the profile after the surgical removal of the tumors. The proportion of the identified metabolites in the serum samples $(65 \%)$ and the urine samples (35\%) was not statistically different. However, the pattern of the dysregulation of 
the metabolites after surgery was distinct. A higher proportion of metabolites increased in concentration after surgery in the serum and urine samples, and in the serum samples only compared to the urine samples. In contrast, the proportion of urinary metabolites that were increased or decreased after surgery was similar. The allocated chemical class of metabolite did not influence the proportion of metabolites following a particular trajectory of dysregulation after surgery (Figure 2). The magnitude of the downregulation of the metabolites after surgery was higher in both the serum and urine samples, although this was not statistically significant; the difference was larger in the urine samples. (Table 4 and Figure 3).

\subsection{Lipids and Derivatives}

Among the identified classes of metabolites, lipids were the most frequently identified and included fatty acids, bile acids, carnitines, phosphatidylglycerol, phosphatidylinositol, prostaglandins, and products of the mevalonate pathway. All lipid metabolites except one were identified in the serum samples. Most lipid metabolites (80\%) were upregulated after surgery with a moderate change in their profile (median $\mathrm{FC}=4$ ). Isopentenyladenine, the only lipid identified in the urine samples linked to the mevalonate pathway, was downregulated (median FC $=31$ ). Based on our review of the literature, the most common lipid metabolic alterations linked to carcinogenesis are in fatty acid metabolism, arachidonic acid metabolism, cholesterol metabolism, and peroxisome proliferator-activated receptors (PPAR) signaling [25]. PPAR plays a significant role in chronic inflammatory conditions leading to cancer development [26]. The uptake, activation, and synthesis of fatty acids by tumors is facilitated through enzymes such as acetyl coenzyme A, and fatty acid synthase (FASN) $[27,28]$. The upregulation of FAS in early-stage lung cancer tumors has been associated with aggressive clinical behavior and a poor prognosis $[29,30]$. The key enzyme stearoyl coenzyme A desaturase 1 (SCD1), involved in the formation of palmitoleic and oleic acids has been implicated in adenocarcinomas of the lung in tumor initiation and invasion and is a potential target for therapeutic intervention [31]. Members of the adenosine triphosphate-binding cassette $(A B C)$ family of proteins have been correlated with a poor response to platinum-based chemotherapy in NSLC [32]. ATP citrate lyase (ACLY), which is involved in fatty acid synthesis, has been associated with tumorigenesis and is a potential prognostic biomarker [28,33]. In the current study, 2-propylpent-3-enoic acid, a fatty acid, was upregulated in the serum samples by 50 -fold post-surgery. We could not find any previous association of this metabolite to the pathogenesis of cancer. Isopentenyladenine, a product of the mevalonate pathway, decreased by 31-fold in the urine samples after surgery. The mevalonate pathway is frequently overactive in cancer cells [34] and regulates cholesterol synthesis and the formation of 3-hydroxy-3-methylgrutaryl coenzyme A (HMG-CoA). HMG-CoA is reduced to mevalonate by HMG-CoA reductase (HMGCR); HMGCR is a potential therapeutic target for cholesterol lowering drugs (such as statins) to treat cancer [34-37]. Chenodeoxycholic/deoxycholic/glycoursodeoxycholic acid, a bile acid, was upregulated by 28 -fold in serum post-surgery. Bile acids have been implicated in the pathogenesis of several malignancies including colorectal, breast, hepatocellular, and renal cancers $[38,39]$.

\subsection{Proteins and Derivatives}

Of the metabolites we identified, $23 \%$ were related to protein metabolism, with almost similar frequencies of up- and downregulation. However, as a class of metabolites, the overall magnitude of the alteration and the decrease in the metabolite levels after surgery was significant (Table 4, Figure 3). Cancer cells proliferate and survive by upregulating the synthesis of essential and nonessential amino acids, facilitated by specific transport systems, stromal cells, gene silencing, and redox homeostasis. Various cell signaling pathways are altered to generate nucleotides, reactive oxygen species (ROS), scavenging molecules, and oncometabolites to favor the proliferation of cancer cells [40-42]. We found that two metabolites identified in the urine samples, leucyl proline (Pro Leu) and 
ADMA, which have previously been associated with cancer pathogenesis, profoundly decreased after surgery (Table 5). Pro Leu, a dipeptide composed of L-leucine and L-proline, was downregulated by 625 -fold in urine. Recent reviews have highlighted a clinically significant role for proline in cancer metabolism [43]. Through a series of reactions, proline metabolism is initiated by converting proline into pyrroline-5-carboxylate, facilitated by the enzyme proline dehydrogenase/proline oxidase (PRODH/POX). High levels of proline result in the upregulation of PRODH, which in turn results in the production of ROS. PRODH is induced by p53 and can be up- or downregulated depending upon the type of the cancer and cell environment [44]. ADMA, an amino acid, decreased by 16-fold in urine post-surgery. Higher levels of this metabolite have been found in lung cancer patients [45]. The dipeptide aspartyl glycine was downregulated by 50 -fold in urine. Pre-clinical studies using cancer cell lines have indicated that glycine consumption and the mitochondrial glycine biosynthetic pathway are associated with cancer cell proliferation [46]. Glutamic acid n-butyl ester was upregulated in urine by 65 -fold. Glutamic acid (glutamate) is a proteinogenic nonessential amino acid and a bioenergetic substrate for proliferating malignant cells. It is involved in tumor development as a growth factor and a signal mediator facilitated through metabotropic glutamate receptors and ionotropic glutamate receptors found in cancerous tumors [47].

\subsection{Purines and Pyrimidines}

Purines are the most commonly found metabolites in normal cells. They are the primary building blocks in DNA and RNA synthesis and provide the energy and cofactors needed for normal and essential cellular functions [48]. Altered purine metabolism in cancer cells is a component of proliferation, tumor immune response, invasiveness, and metastasis and has led to novel therapeutic interventions in the field of oncology such as the antipurine metabolite drugs 6-mercaptopurine, 6-thioguanine, and methotrexate [49]. In this study, the magnitude of the alteration of purines after surgery was significant (Table 4 and Figure 3). Noticeably, N6-methyladenosine was identified in urine, and was upregulated by 27 -fold post-surgery. N6-methyladenosine is an endogenous methylated adenine produced by the degradation of transfer ribonucleic acid (tRNA) and found in urine [23]. This is the most commonly identified post-transcriptional modification of mRNA and is primarily a reversible process facilitated by the enzymes methyltransferase and demethylase. Recent research has revealed a critical role for N6-methyladenosine in the oncogene regulation and pathogenesis of several human cancers, including NSCLC [50-53]. Methyl uric acid, a xanthine and a purine derivative, was downregulated by 198 -fold. Uric acid metabolism may have a potential role in carcinogenesis through its role both as an anti and pro oxidant [54]. In a small pilot study involving breast cancer patients, urinary methyl uric acid identified by LC-QTOF was reduced by 0.6 -fold in urine compared to the patients with no cancer [55].

\subsection{Carboxylic Acid Derivatives and Carbohydrates}

There were seven metabolites identified as carboxylic acid or derivatives. Fumaric acid was found to be decreased by 17 -fold after surgery and was detected in the urine samples. This is one of compounds of the Krebs cycle and a biproduct of succinic acid oxidation. It has been found to be significantly altered in the serum of lung cancer patients compared to healthy individuals $[56,57]$.

The altered glucose metabolism in cancer cells has been known for the past 100 years and is based on the "Warburg effect", which is related to the increased uptake and utilization of glucose with disproportionately increased lactate production by proliferating cancer cells in the presence of sufficient oxygen or hypoxic conditions [58]. In our study, all identified metabolites related to carbohydrates were upregulated with a relatively minimal change (median FC = 2), except beta-cortol, which was downregulated by 8 -fold and found in the serum samples. Beta-cortol belongs to a group of cortisol metabolites that are O-glycosyl compounds, in which a sugar is bonded through one carbon to another group 
via a O-glycosidic bond [36]. An altered cortisol metabolism has been demonstrated in advanced cancers [59]. There is evidence that microcellular lung cancer produces ACTH (and hence increased cortisol levels), which could serve as potential biomarker for the early diagnosis of lung cancer [60].

\subsection{Endocrine Factors}

The androgens androstanediol and androstenedione were identified in the serum samples. While androstenedione was modestly elevated $(\mathrm{FC}=8)$, androstanediol was downregulated by 54 -fold. Androgens may have a role in the pathophysiology of lung cancer as androgen receptors have been found in lung cancer tumors. A retrospective study of NSCLC patients by Harlos et al. [61] indicated that androgen pathway manipulation was prognostic and associated with improved survival in lung cancer patients who received 5-alpha reductase inhibitors. Dopamine and epinephrine are catecholamines. Both were upregulated after surgery and identified in the serum samples. While dopamine only increased by 5 -fold, epinephrine increased by 134 -fold post-surgery. These compounds have opposite roles in tumor angiogenesis. Dopamine and epinephrine inhibit and promote tumor angiogenesis, respectively [62]. Tetrahydrobiopterin/sapropterin (BH4, THB) is a biopterin that was upregulated post-surgery by 8 -fold. Biopterin may have a role in tumor progression [63]. N-desmethylaminopyrine, a phenyl pyrazole, increased by 10 -fold in serum. We could not find any previously known association of this compound to carcinogenesis.

A summary of the metabolites of significance in this study and the associated metabolic pathways employed in carcinogenesis is presented in Table 6.

Table 6. Metabolites of significance and the associated metabolic pathways.

\begin{tabular}{|c|c|c|}
\hline Metabolite & Regulation & Metabolic Pathway \\
\hline Pro Leu & down & $\begin{array}{l}\text { Proline metabolism facilitated by } \\
\text { PRODH/POX }\end{array}$ \\
\hline 3-Methyluric acid & down & Purine Metabolism \\
\hline Androstanediol & down & Androgen pathway through AR in NSCLC \\
\hline Aspartyl glycine & down & Mitochondrial glycine biosynthetic pathway \\
\hline Isopentenyladenine & down & Mevalonate pathway \\
\hline Fumaric acid & down & Krebs cycle \\
\hline Asymmetric dimethylarginine (ADMA) & down & $\begin{array}{c}\text { Overexpression of protein arginine methyl } \\
\text { transferase }\end{array}$ \\
\hline Epinephrine & up & Angiogenesis \\
\hline 2-Propylpent-3-enoic acid & up & Fatty acid metabolism \\
\hline L-Glutamic acid n-butyl ester & up & $\begin{array}{l}\text { Growth factor, metabotropic/ionotropic } \\
\text { glutamate receptors }\end{array}$ \\
\hline $\begin{array}{l}\text { Chenodeoxycholic/Deoxycholic/ } \\
\text { Glycoursodeoxycholic acid }\end{array}$ & up & Over expressed FXR \\
\hline N6-Methyladenosine & up & Degradation of $\mathrm{tRNA}$ \\
\hline
\end{tabular}

Notes: AR, androgen receptors; FXR, farnesoid X receptor; NSCLC, non-small cell lung cancer; PRODH/POX, proline dehydrogenase/proline oxidase; tRNA, transfer ribonucleic acid.

\subsection{Strengths and Limitations of the Study}

This study is limited by the small sample size and the large number of metabolites which were assessed. These two factors render this study underpowered for any meaningful multivariable analysis to determine the effect of clinical and pathological variables on the metabolic profile of this cohort. Nonetheless, this study is designed to address the effect of treatment intervention (i.e., surgical tumor extraction) on the patient's metabolic profile. The pre- and post-exposure design set up each patient to serve as their own control, thus eliminating any bias introduced by comparisons between individuals. Furthermore, surgical resection in early-stage cancer patients achieves a more complete eradication of cancer compared to radiation and/or systemic (chemo) therapy. Surgery thus represents a unique intervention to compare two metabolic states in the same patient population, which may be considered "with" and "without" cancer. 


\section{Conclusions}

We have conducted a prospective observational study in a single cohort of early-stage NSCLC patients to compare biofluid metabolomics before and after the surgical removal of pulmonary tumors. We detected a dysregulation of the primary metabolic pathways in urine and serum samples by both NMR and LC-QTOF-MS, evidenced by the changes in 31 and 17 metabolites in the serum and urine samples, respectively, obtained from 35 patients. There was no significant difference in the distribution of metabolites between the serum and urine samples, but the pattern of dysregulation was different. More metabolites were upregulated in the serum samples with a consistent pattern of dysregulation in the urinary metabolites after surgery. The chemical class of the metabolites did not influence the proportion of metabolites that were up- or downregulated. The magnitude of downregulation after surgery was higher than that of upregulation in both the serum and urine samples, and although not statistically significant, this difference was larger in the urine samples. Alteration in purines/pyrimidines and proteins and derivatives was larger than that of other classes of metabolites detected in our study, suggesting the importance of these as potential biomarkers for screening, diagnostics, or monitoring. Based on the magnitude of alteration and the previously known association to NSCLC and/or any other cancer, we identified six metabolites of significance: in both the serum and urine samples, leucyl proline, ADMA, isopentenyladenine, and fumaric acid were downregulated after surgery; N6-methyladenosine and deoxycholic acid moieties were upregulated. Four other metabolites with a significant dysregulation, FC $>100$ after surgery, included 3-methyl uric acid, N(alpha)-t-butoxycarbonyl-L-leucine, hypoglycin, and epinephrine; there is no known direct association of these metabolites to cancer pathogenesis, and this is a new observation. Further studies with larger cohorts that include patients with advanced-stage lung cancer are warranted to expand on our findings and progress toward the clinical application of metabolomics in cancer diagnosis and treatment.

Author Contributions: Conceptualization, N.A., M.A., B.K.; methodology, N.A., B.K., M.A.; software, M.A.; validation, N.A. and M.A.; formal analysis, N.A., Z.N.; investigation, N.A., M.A., L.W., N.M.; resources, N.A., M.A., B.K., L.T., G.B., S.K.S., A.M., S.S.-I., G.Q.; data curation, N.A., Z.N.; original draft preparation, N.A.; manuscript review and editing, N.A., M.A., B.K., N.M., L.W.; supervision, N.A.; project administration, N.A., M.A., L.W.; funding acquisition, N.A. All authors have read and agreed to the published version of the manuscript.

Funding: This research was funded by the CancerCare Manitoba Foundation, grant number 761075015.

Institutional Review Board Statement: The study was conducted according to the guidelines of the Declaration of Helsinki and approved by the Institutional Review Board of the University of Manitoba, protocol code H2017:247, approved 31 July 2017.

Informed Consent Statement: Informed consent was obtained from all subjects involved in the study.

Data Availability Statement: Metabolite data from NMR and LC-QTOF-MS, not reported in Table 2 is available on: https://doi.org/10.6084/m9.figshare.14781396.v1.

Conflicts of Interest: The authors declare no conflict of interest. The funders had no role in the design of the study; in the collection, analyses, or interpretation of data; in the writing of the manuscript; or in the decision to publish the results.

\section{References}

1. Schvartsman, G.; Ferrarotto, R.; Massarelli, E. Checkpoint inhibitors in lung cancer: Latest developments and clinical potential. Ther. Adv. Med. Oncol. 2016, 8, 460-473. [CrossRef] [PubMed]

2. Barlesi, F.; Mazieres, J.; Merlio, J.-P.; Debieuvre, D.; Mosser, J.; Lena, H.; Ouafik, L.H.; Besse, B.; Rouquette, I.; Westeel, V. Routine molecular profiling of patients with advanced non-small-cell lung cancer: Results of a 1-year nationwide programme of the French Cooperative Thoracic Intergroup (IFCT). Lancet 2016, 387, 1415-1426. [CrossRef]

3. Rosell, R.; Karachaliou, N. Large-scale screening for somatic mutations in lung cancer. Lancet 2016, 387, 1354-1356. [CrossRef]

4. Kris, M.G.; Johnson, B.E.; Berry, L.D.; Kwiatkowski, D.J.; Iafrate, A.J.; Wistuba, I.I.; Varella-Garcia, M.; Franklin, W.A.; Aronson, S.L.; Su, P.-F. Using multiplexed assays of oncogenic drivers in lung cancers to select targeted drugs. JAMA J. Am. Med. Assoc. 2014, 311, 1998-2006. [CrossRef] [PubMed] 
5. Warburg, O. On the origin of cancer cells. Science 1956, 123, 309-314. [CrossRef] [PubMed]

6. Vander Heiden, M.G.; Cantley, L.C.; Thompson, C.B. Understanding the Warburg effect: The metabolic requirements of cell proliferation. Science 2009, 324, 1029-1033. [CrossRef] [PubMed]

7. Bamji-Stocke, S.; van Berkel, V.; Miller, D.M.; Frieboes, H.B. A review of metabolism-associated biomarkers in lung cancer diagnosis and treatment. Metabolomics 2018, 14, 81. [CrossRef]

8. Yu, L.; Li, K.; Zhang, X. Next-generation metabolomics in lung cancer diagnosis, treatment and precision medicine: Mini review. Oncotarget 2017, 8, 115774-115786. [CrossRef] [PubMed]

9. Seijo, L.M.; Peled, N.; Ajona, D.; Boeri, M.; Field, J.K.; Sozzi, G.; Pio, R.; Zulueta, J.J.; Spira, A.; Massion, P.P.; et al. Biomarkers in Lung Cancer Screening: Achievements, Promises, and Challenges. J. Thorac. Oncol. 2019, 14, 343-357. [CrossRef]

10. Mathe, E.A.; Patterson, A.D.; Haznadar, M.; Manna, S.K.; Krausz, K.W.; Bowman, E.D.; Shields, P.G.; Idle, J.R.; Smith, P.B.; Anami, K.; et al. Noninvasive urinary metabolomic profiling identifies diagnostic and prognostic markers in lung cancer. Cancer Res. 2014, 74, 3259-3270. [CrossRef]

11. Haznadar, M.; Cai, Q.; Krausz, K.W.; Bowman, E.D.; Margono, E.; Noro, R.; Thompson, M.D.; Mathe, E.A.; Munro, H.M.; Steinwandel, M.D.; et al. Urinary Metabolite Risk Biomarkers of Lung Cancer: A Prospective Cohort Study. Cancer Epidemiol. Prev. Biomark. 2016, 25, 978-986. [CrossRef] [PubMed]

12. Ros-Mazurczyk, M.; Wojakowska, A.; Marczak, L.; Polanski, K.; Pietrowska, M.; Polanska, J.; Dziadziuszko, R.; Jassem, J.; Rzyman, W.; Widlak, P. Panel of serum metabolites discriminates cancer patients and healthy participants of lung cancer screening-A pilot study. Acta Biochim. Pol. 2017, 64, 513-518. [CrossRef]

13. Fahrmann, J.F.; Grapov, D.; DeFelice, B.C.; Taylor, S.; Kim, K.; Kelly, K.; Wikoff, W.R.; Pass, H.; Rom, W.N.; Fiehn, O.; et al. Serum phosphatidylethanolamine levels distinguish benign from malignant solitary pulmonary nodules and represent a potential diagnostic biomarker for lung cancer. Cancer Biomark. 2016, 16, 609-617. [CrossRef]

14. Cameron, S.J.; Lewis, K.E.; Beckmann, M.; Allison, G.G.; Ghosal, R.; Lewis, P.D.; Mur, L.A. The metabolomic detection of lung cancer biomarkers in sputum. Lung Cancer 2016, 94, 88-95. [CrossRef] [PubMed]

15. Peralbo-Molina, A.; Calderon-Santiago, M.; Priego-Capote, F.; Jurado-Gamez, B.; Luque de Castro, M.D. Identification of metabolomics panels for potential lung cancer screening by analysis of exhaled breath condensate. J. Breath Res. 2016, 10, 026002 [CrossRef]

16. Ahmed, N.; Bezabeh, T.; Ijare, O.B.; Myers, R.; Alomran, R.; Aliani, M.; Nugent, Z.; Banerji, S.; Kim, J.; Qing, G. Metabolic Signatures of Lung Cancer in Sputum and Exhaled Breath Condensate Detected by 1H Magnetic Resonance Spectroscopy: A Feasibility Study. Magn. Reson. Insights 2016, 9, 29. [CrossRef]

17. Tang, Y.; Li, Z.; Lazar, L.; Fang, Z.; Tang, C.; Zhao, J. Metabolomics workflow for lung cancer: Discovery of biomarkers. Clin. Chim. Acta 2019, 495, 436-445. [CrossRef] [PubMed]

18. Tee, S.-S.; Keshari, K.R. Novel approaches to imaging tumor metabolism. Cancer J. 2015, 21, 165. [CrossRef]

19. García-Figueiras, R.; Baleato-González, S.; Padhani, A.R.; Oleaga, L.; Vilanova, J.C.; Luna, A.; Gómez, J.C.C. Proton magnetic resonance spectroscopy in oncology: The fingerprints of cancer? Diagn. Interv. Radiol. 2016, 22, 75. [CrossRef]

20. Ahmed, N.; Kidane, B.; Wang, L.; Qing, G.; Tan, L.; Buduhan, G.; Srinathan, S.; Aliani, M. Non-invasive exploration of metabolic profile of lung cancer with Magnetic Resonance Spectroscopy and Mass Spectrometry. Contemp. Clin. Trials Commun. 2019, 16, 100445. [CrossRef] [PubMed]

21. Xi, B.; Gu, H.; Baniasadi, H.; Raftery, D. Statistical analysis and modeling of mass spectrometry-based metabolomics data. In Mass Spectrometry in Metabolomics; Springer: New York, NY, USA, 2014; pp. 333-353.

22. Smith, C.A.; O’Maille, G.; Want, E.J.; Qin, C.; Trauger, S.A.; Brandon, T.R.; Custodio, D.E.; Abagyan, R.; Siuzdak, G. METLIN: A metabolite mass spectral database. Ther. Drug Monit. 2005, 27, 747-751. [CrossRef]

23. Wishart, D.S.; Feunang, Y.D.; Marcu, A.; Guo, A.C.; Liang, K.; Vázquez-Fresno, R.; Sajed, T.; Johnson, D.; Li, C.; Karu, N. HMDB 4.0: The human metabolome database for 2018. Nucleic Acids Res. 2018, 46, D608-D617. [CrossRef]

24. Sayers, E.W.; Barrett, T.; Benson, D.A.; Bolton, E.; Bryant, S.H.; Canese, K.; Chetvernin, V.; Church, D.M.; DiCuccio, M.; Federhen, S. Database resources of the national center for biotechnology information. Nucleic Acids Res. 2010, 39, D38-D51. [CrossRef]

25. Hao, Y.; Li, D.; Xu, Y.; Ouyang, J.; Wang, Y.; Zhang, Y.; Li, B.; Xie, L.; Qin, G. Investigation of lipid metabolism dysregulation and the effects on immune microenvironments in pan-cancer using multiple omics data. BMC Bioinform. 2019, 20, 29-39. [CrossRef]

26. Liu, Y.; Colby, J.K.; Zuo, X.; Jaoude, J.; Wei, D.; Shureiqi, I. The role of PPAR- $\delta$ in metabolism, inflammation, and cancer: Many characters of a critical transcription factor. Int. J. Mol. Sci. 2018, 19, 3339. [CrossRef]

27. Röhrig, F.; Schulze, A. The multifaceted roles of fatty acid synthesis in cancer. Nat. Rev. Cancer 2016, 16, 732. [CrossRef] [PubMed]

28. Salvador, M.M.; de Cedrón, M.G.; Rubio, J.M.; Martínez, S.F.; Martínez, R.S.; Casado, E.; de Molina, A.R.; Sereno, M. Lipid metabolism and lung cancer. Crit. Rev. Oncol. Hematol. 2017, 112, 31-40. [CrossRef] [PubMed]

29. Visca, P.; Sebastiani, V.; Botti, C.; Diodoro, M.G.; Lasagni, R.P.; Romagnoli, F.; Brenna, A.; De Joannon, B.C.; Donnorso, R.P.; Lombardi, G. Fatty acid synthase (FAS) is a marker of increased risk of recurrence in lung carcinoma. Anticancer Res. 2004, 24, 4169-4174. [PubMed]

30. Wang, Y.; Zhang, X.; Tan, W.; Fu, J.; Zhang, W. Significance of fatty acid synthase expression in non-small cell lung cancer. Zhonghua Zhong Liu Za Zhi Chin. J. Oncol. 2002, 24, 271-273.

31. Huang, J.; Fan, X.-X.; He, J.; Pan, H.; Li, R.-Z.; Huang, L.; Jiang, Z.; Yao, X.-J.; Liu, L.; Leung, E.L.-H. SCD1 is associated with tumor promotion, late stage and poor survival in lung adenocarcinoma. Oncotarget 2016, 7, 39970. [CrossRef] 
32. Yoh, K.; Ishii, G.; Yokose, T.; Minegishi, Y.; Tsuta, K.; Goto, K.; Nishiwaki, Y.; Kodama, T.; Suga, M.; Ochiai, A. Breast cancer resistance protein impacts clinical outcome in platinum-based chemotherapy for advanced non-small cell lung cancer. Clin. Cancer Res. 2004, 10, 1691-1697. [CrossRef]

33. Butler, L.; Perone, Y.; Dehairs, J.; Lupien, L.E.; de Laat, V.; Talebi, A.; Loda, M.; Kinlaw, W.B.; Swinnen, J.V. Lipids and cancer: Emerging roles in pathogenesis, diagnosis and therapeutic intervention. Adv. Drug Deliv. Rev. 2020. [CrossRef]

34. Thurnher, M.; Gruenbacher, G.; Nussbaumer, O. Regulation of mevalonate metabolism in cancer and immune cells. Biochim. Biophys. Acta BBA Mol. Cell Biol. Lipids 2013, 1831, 1009-1015. [CrossRef]

35. Fiala, O.; Pesek, M.; Finek, J.; Minarik, M.; Benesova, L.; Bortlicek, Z.; Topolcan, O. Statins augment efficacy of EGFR-TKIs in patients with advanced-stage non-small cell lung cancer harbouring KRAS mutation. Tumor Biol. 2015, 36, 5801-5805. [CrossRef] [PubMed]

36. Göbel, A.; Rauner, M.; Hofbauer, L.C.; Rachner, T.D. Cholesterol and beyond-the role of the mevalonate pathway in cancer biology. Biochim. Biophys. Acta BBA Rev. Cancer 2020, 1873, 188351. [CrossRef] [PubMed]

37. Hassanabad, A.F.; Mina, F. Targeting the Mevalonate Pathway for Treating Lung Cancer. Am. J. Clin. Oncol. 2020, 43, 69-70. [CrossRef] [PubMed]

38. Debruyne, P.R.; Bruyneel, E.A.; Li, X.; Zimber, A.; Gespach, C.; Mareel, M.M. The role of bile acids in carcinogenesis. Mutat. Res. Fundam. Mol. Mech. Mutagenesis 2001, 480, 359-369. [CrossRef]

39. Di Ciaula, A.; Wang, D.Q.-H.; Molina-Molina, E.; Baccetto, R.L.; Calamita, G.; Palmieri, V.O.; Portincasa, P. Bile acids and cancer: Direct and environmental-dependent effects. Ann. Hepatol. 2017, 16, S87-S105. [CrossRef]

40. Muhammad, N.; Lee, H.M.; Kim, J. Oncology therapeutics targeting the metabolism of amino acids. Cells 2020, 9, 1904. [CrossRef]

41. Vettore, L.; Westbrook, R.L.; Tennant, D.A. New aspects of amino acid metabolism in cancer. Br. J. Cancer 2020, 122, 150-156. [CrossRef]

42. Lieu, E.L.; Nguyen, T.; Rhyne, S.; Kim, J. Amino acids in cancer. Exp. Mol. Med. 2020, 52, 15-30. [CrossRef]

43. Phang, J.M. Proline metabolism in cell regulation and cancer biology: Recent advances and hypotheses. Antioxid. Redox Signal. 2019, 30, 635-649. [CrossRef]

44. D'aniello, C.; Patriarca, E.J.; Phang, J.M.; Minchiotti, G. Proline metabolism in tumor growth and metastatic progression. Front. Oncol. 2020, 10, 776. [CrossRef]

45. Bayraktutan, Z.; Kiziltunc, A.; Bakan, E.; Alp, H.H. Determination of Endothelial Nitric Oxide Synthase Gene Polymorphism and Plasma Asymmetric Dimethyl Arginine Concentrations in Patients with Lung Cancer. Eurasian J. Med. 2020, 52, 185. [CrossRef] [PubMed]

46. Jain, M.; Nilsson, R.; Sharma, S.; Madhusudhan, N.; Kitami, T.; Souza, A.L.; Kafri, R.; Kirschner, M.W.; Clish, C.B.; Mootha, V.K. Metabolite profiling identifies a key role for glycine in rapid cancer cell proliferation. Science 2012, 336, 1040-1044. [CrossRef] [PubMed]

47. Stepulak, A.; Rola, R.; Polberg, K.; Ikonomidou, C. Glutamate and its receptors in cancer. J. Neural Transm. 2014, 121, 933-944. [CrossRef] [PubMed]

48. Pedley, A.M.; Benkovic, S.J. A new view into the regulation of purine metabolism: The purinosome. Trends Biochem. Sci. 2017, 42, 141-154. [CrossRef]

49. Yin, J.; Ren, W.; Huang, X.; Deng, J.; Li, T.; Yin, Y. Potential mechanisms connecting purine metabolism and cancer therapy. Front. Immunol. 2018, 9, 1697. [CrossRef] [PubMed]

50. Deng, X.; Su, R.; Feng, X.; Wei, M.; Chen, J. Role of N6-methyladenosine modification in cancer. Curr. Opin. Genet. Dev. 2018, 48, 1-7. [CrossRef]

51. He, L.; Li, H.; Wu, A.; Peng, Y.; Shu, G.; Yin, G. Functions of N6-methyladenosine and its role in cancer. Mol. Cancer 2019, 18, 1-15. [CrossRef]

52. Zhu, Z.; Qian, Q.; Zhao, X.; Ma, L.; Chen, P. N6-methyladenosine ALKBH5 promotes non-small cell lung cancer progress by regulating TIMP3 stability. Gene 2020, 731, 144348. [CrossRef]

53. Xu, R.; Pang, G.; Zhao, Q.; Yang, L.; Chen, S.; Jiang, L.; Shen, Y.; Shao, W. The momentous role of N6-methyladenosine in lung cancer. J. Cell. Physiol. 2020, 236, 3244-3256. [CrossRef]

54. Yiu, A.; Van Hemelrijck, M.; Garmo, H.; Holmberg, L.; Malmström, H.; Lambe, M.; Hammar, N.; Walldius, G.; Jungner, I.; Wulaningsih, W. Circulating uric acid levels and subsequent development of cancer in 493,281 individuals: Findings from the AMORIS Study. Oncotarget 2017, 8, 42332. [CrossRef]

55. Park, J.; Shin, Y.; Kim, T.H.; Kim, D.-H.; Lee, A. Urinary Metabolites as Biomarkers for Diagnosis of Breast Cancer: A Preliminary Study. J. Breast Dis. 2019, 7, 44-51. [CrossRef]

56. Zhang, L.; Zheng, J.; Ahmed, R.; Huang, G.; Reid, J.; Mandal, R.; Maksymuik, A.; Sitar, D.S.; Tappia, P.S.; Ramjiawan, B. A high-performing plasma metabolite panel for early-stage lung cancer detection. Cancers 2020, 12, 622. [CrossRef]

57. Hori, S.; Nishiumi, S.; Kobayashi, K.; Shinohara, M.; Hatakeyama, Y.; Kotani, Y.; Hatano, N.; Maniwa, Y.; Nishio, W.; Bamba, T. A metabolomic approach to lung cancer. Lung Cancer 2011, 74, 284-292. [CrossRef]

58. Bose, S.; Le, A. Glucose metabolism in cancer. Heterog. Cancer Metab. 2018, 1063, 3-12.

59. Werk, E.E., Jr.; MacGee, J.; Sholiton, L.J. Altered cortisol metabolism in advanced cancer and other terminal illnesses: Excretion of 6-hydroxycortisol. Metabolism 1964, 13, 1425-1438. [CrossRef] 
60. Milosevic, I. Immunofluorometrical Exploring of FSH Levels in the Serum of Patients with Histologically Verified Macrocellular Lung Cancer. Clin. Immunol. 2007, S50-S51. [CrossRef]

61. Harlos, C.; Musto, G.; Lambert, P.; Ahmed, R.; Pitz, M.W. Androgen pathway manipulation and survival in patients with lung cancer. Horm. Cancer 2015, 6, 120-127. [CrossRef] [PubMed]

62. Chakroborty, D.; Sarkar, C.; Basu, B.; Dasgupta, P.S.; Basu, S. Catecholamines regulate tumor angiogenesis. Cancer Res. 2009, 69, 3727-3730. [CrossRef] [PubMed]

63. Rabender, C.; Alam, A.; Waters, M.; Mikkelsen, R. Biopterin metabolism drives tumor progression. Cancer Res. 2015, 75. [CrossRef] 